\title{
Shrimps between Whales or Small but Piquant Peppers?: Foreign Policy Choices of Korea and Poland
}

\author{
TAE-HyUng KIM ${ }^{*}$ AND JiYOUNG KIM ${ }^{* *}$
}

\begin{abstract}
Recognizing that few scholars have explored the foreign policy of non-major powers, in this paper, we explore the patterns of non-major powers' foreign policy through a historical comparison of Korea and Poland. Despite substantial differences, the modern histories of Korea and Poland share significant similarities due mainly to their geographic locations between two great powers: Korea between China and Japan, and Poland between Germany and Russia. Their unfavorable locations have constantly forced the two nations to adjust and accommodate to changing external environments they cannot control. Through this comparative case study of Korea and Poland, we also highlight the limitations of the existing realist approach in explaining foreign policy behaviors of non-major powers.
\end{abstract}

Keywords: Foreign Policy, Foreign Policy Behavior, Non-Major Powers, Korea, Poland

Assistant Professor, Department of Political Science and International Relations, Soongsil University, Seoul, Korea. E-mail:tkim2002@ssu.ac.kr

*** Ewha-KOICA Professor, Graduate School of International Studies, Ewha Womans University, South Korea. E-mail:jiyoung.kim@ewha.ac.kr 


\section{INTRODUCTION}

$\mathrm{D}$

espite substantial differences, the modern histories of Korea and Poland share significant similarities due to their geographic locations between two great powers: Korea between China and Japan, and Poland between Germany and Russia. Their unfavorable locations have constantly forced the two nations to adjust and accommodate to changing external environments they cannot control. The two unfortunates endured partition, occupation, or colonization for significant periods in their modern history. The asymmetry of power also pressured the two into client relationships with much more powerful neighbors, especially during the Cold War. Such is the situation of a shrimp between two whales, in the imagery of a colorful Korean expression.

Recognizing that few scholars have explored the foreign policy of non-major powers, we explore the patterns of non-major powers' foreign policy through a historical comparison of Korea and Poland. Since the literature on realism in general, and neorealist foreign policy in particular, has almost exclusively focused on European major powers, we believe it is meaningful to evaluate and compare foreign policy behaviors of a non-Western, non-major power (Korea) and a European non-major power (Poland). In this article, we first outline the theoretical and historical background. We then examine the histories of Poland and Korea through the end of the Cold War, focusing on foreign relations and policy behaviors in response to external threats. We conclude with a comparative analysis of the two countries and some discussion of policy implications.

\section{NEOREALISM AND THE PREDICAMENT OF BUFFER STATES}

Neorealism focuses mainly on material power and system-level power distribution, so it has inevitably overlooked less powerful nations within the system and non-European continents. It has also been limited to a post-Westphalia timeframe, which has brought sharp criticism from Buzan and Little (2000, 18-20), leading scholars of the English School, who charged that (neo) realism is not only Eurocentric but also ahistorical. Yet as Miriam Elman (1995, 175) cites, "since small states are more preoccupied with survival than great powers, the international system-external threat-will be the most relevant level of analysis for explaining their foreign-policy choices." Neorealism is expected to dominate small states' foreign policy behaviors as well.

Neorealists have been fiercely debating over the concept of balance of power, which was developed to explain the behaviors of major European powers (Sheehan 1996; Donnelly 2000; Vazquez and Elman 2002; Paul, Wirtz, and Fortmann 2004; Levy 2005; Little 2007; Kaufman, Little, and Wohlforth 2007). This means lesser powers would behave differently from major powers when confronting 
a threat. In the European balance of power system in recent centuries, major powers tried to preserve equilibrium at the expense of the weak. Thus, "while it can be argued that sacrificing weak states to maintain the balance of power serves the good of the system, it will clearly weaken the commitment of weak states to the balance of power as a system, since it does not serve their interests in the same way it does those of the great powers" (Sheehan 1996, 74). In other words, non-major powers need ways other than balancing to maintain security. Walt argues that weak states generally balance against other weak states with roughly equal capabilities but are more likely to bandwagon when threatened by stronger states. ${ }^{1}$ Moreover, when faced with external threats, states could underbalance-a failure to balance due to internal disagreements that disrupt elite cohesion (Schweller 2006).

Yet the analyses of balancing and bandwagoning are also products of the European experience. They presume a setting of multipolar anarchy, an uncommon situation for East Asia, which has been dominated by Chinese preponderance for centuries (Kang 2007). Thus, a unipolar hierarchy has characterized East Asia through most of history. ${ }^{2}$ In these circumstances, powers on the periphery of China, like Korea, are likely to stay within the regional order created and managed through Chinese primacy, as long as it preserves their sovereignty. Yet when Chinese dominance was challenged beginning in the mid-nineteenth century, Korea's choices became broader but harder. Under certain conditions, states have options beyond balancing or bandwagoning. Refuting the neorealist claim that balancing is the general behavior of threatened states, Schroeder (1994, 117) argues that states instead bandwagon, hide, or transcend. Kaufman, Little, and Wohlforth $(2007,11)$ agree that states, especially non-major powers, "whose power falls in the middle of this range should prefer to balance if the threat is high, but may not be able to. If not, they can be expected to follow ambiguous hedging strategies." Kang $(2007,53)$ also argues that between the extremes of balancing and bandwagoning, countries can hedge when they fear another state (but not enough to balance), and they can accommodate when they do not fear another state, and seek ways to "cooperate and craft stability that are short of slavish bandwagoning." Labs (1992, 393-94), after summarizing existing literature on weak states' behavior when threatened by great powers, lists policy options for weaker states: nonalignment, balance with a protecting great power for a free-ride, balance with a protecting great power and fight, seek an alliance of weak states, fight alone, and bandwagon. In sum, behaviors of non-major states are heavily influenced by the external environment, especially their neighboring great power politics, and these states are unlikely to be able to succeed in balancing against such a formidable challenge. They try to choose among various options mentioned above for survival, yet achieving their goal might be awfully difficult in harsh reality. Proper action could be even tougher if the disagreement of the elites leads to inaction or an incorrect response, namely underbalancing. 
So, why compare Korea and Poland? Are they comparable? After all, they occupy opposite ends of the Eurasian landmass and historically had little contact before the twentieth century. They differ widely in culture, language, and customs. However, both are relatively small vis-à-vis their respective neighbors and possess unfortunate geography. That geography is of vital importance. Fazal (2007) argues that "geography is a key determinant of state death and survival" (1-2), and "states caught between two others engaged in an enduring rivalry-buffer states-are particularly likely to die" (27). Both Korea and Poland did die. Their geography meant that, in the words of a descriptive old Korean phrase, Korea and Poland were each "a shrimp between two whales."

Adopting a comparative historical approach, we demonstrate that, despite differences, one can find notable similarities in their history. For better comparison, we focus on foreign policy choices Korea and Poland made when confronted by difficult decisions imposed by two or more great powers to see if these conform to existing presumptions about non-major powers' foreign policy behaviors. Our analysis reveals that the two nations stood little chance to balance alone due to clear material limitations and the distance of and unreliability of great power allies. Internal divisions and fragmentation made them "underbalanced" (Schweller 2006) in the face of external threats. Their geographic location made hedging, hiding, or bandwagoning nearly impossible, since their territory was the direct target of aggression. There was no place to hide from major powers that were determined to conquer them. Nor could they employ bandwagoning, which is employed by "minor powers that stand alone against hostile great powers" (Mearsheimer 2001, 163) by making "asymmetrical concessions to the aggressor" (Mearsheimer 2001, 463), since only complete conquest of their territory would satisfy the predatory powers. Here lies the tragedy of buffer states between powerful and aggressive neighbors: a shrimp suffers greatly from a fight between two whales. Furthermore, although external conditions cited by neorealists were the dominant factors affecting these two states' foreign policy decisions, ideational and normative factors were sometimes highly influential in policy choices. ${ }^{3}$

\section{KOREA}

\section{Korea under the Chinese Unipolar System}

Before the nineteenth century, most East Asian countries, including Korea and Japan, were more or less under China's tributary system (Lee 1984; Lee 1997; Cumings 1997; Kim 2007; Han 2000; Bang 2005). Countries paid tribute to the Chinese empire; in return, China recognized the sovereignty and political legitimacy of the tributary nation and accorded its security in times of internal or external threat. 
Traditionally, China recognized that Korea was critical to its security by virtue of geography. The Chinese thought it crucial not to have a hostile political regime in Korea lest it become a direct threat to China's national interests. China's perspective was summarized in the phrase, "Without lips (Korea), your teeth (China) are cold." China did not hesitate to intervene militarily to prevent unfriendly regimes from taking power in Korea. This traditional Chinese attitude toward Korea shaped the modern Korea-China relationship.

Geopolitical proximity and significance often forced Korea into political divisions and conflicts during political transitions in China. For instance, during the transition from the Yuan to the Ming in China, Korea also experienced a regime shift, from Koryo to Chosun. The sudden death of King Gongmin, a strong supporter of the incoming Ming dynasty, divided political elites of Koryo into pro-Yuan and pro-Ming groups. Yi Seong Gye, a pro-Ming general, rose against the pro-Yuan leadership of Koryo, who had ordered him to attack the Ming. He established a new kingdom, Chosun, and immediately sought legitimacy through the blessing of the Ming.

Likewise, in the early seventeenth century, China again went through a political transition (from the Ming to the Qing dynasty) that destabilized Korea's Chosun kingdom. In 1616, Nuruhachi unified the Aisin clans and set up the Jin dynasty. In 1644, the Ming finally collapsed and the Qing became the new ruling dynasty in China. During the transition, both the Ming and Jin/Qing pressured Chosun: the Ming asked Chosun for armed assistance, and the Qing asked Chosun to sever diplomatic relations with the Ming. The political elites of Chosun were divided into pro-Ming and pro-Qing groups. After a series of political struggles, the pro-Ming faction gained ascendancy in Chosun, upsetting the Qing, whose power was then surpassing that of the Ming. For the Jin/Qing, it was unacceptable and dangerous to have a hostile government in Chosun. The Jin attacked Chosun in 1627, and the Qing emperor himself led the army that invaded Chosun again in 1636. It did not take long for Chosun to yield to the Qing army. The defeated Chosun dynasty had to accept the demands of the Qing Empire, including severing ties with the Ming and paying tribute to the Qing.

From a realist point of view, it is difficult to explain Chosun's decision to go to war: the Qing's power was palpably overtaking the Ming, and Chosun's weakened army was no match for the Qing's powerful cavalry. This case highlights the importance of ideational factors in shaping Korea's foreign policy: neoConfucian principles compelled the Chosun policymakers to aid the Ming, the ethically right one whose authority came from Heaven. Eckert (2000, 125) summarizes: "To the Korean elite, the Manchus who conquered Ming China were northern barbarians, traditionally outside the circle of civilized countries. .. the ruling elite in Korea continued to look down on the Qing state as culturally inferior."

Throughout the traditional period, China was the only external concern for 
Korea, with one exception: Toyotomi Hideyoshi, who unified Japan and aimed to conquer the Ming. He invaded Korea in 1592. It was the first time Japan challenged China's hegemony in Asia. Located between China and Japan, Korea became the battleground of the two external powers. Japan asked Chosun to allow its army to cross Korea to attack the Ming. Chosun declined and asked the Ming for military support. In June 1592, the Ming, whose power was declining because of internal problems, sent troops to help Chosun and, more importantly, ward off a threat to China's own national security. The war between Japan and the allied forces of Korea and China continued for seven years until Japan withdrew in 1598. The war devastated the peninsula, and hundreds of thousands of Koreans died (Hawley 2005). The experience further solidified Korea's moral and material dependence on, and allegiance to, the Ming, and strengthened the existing Korean antagonism toward the Japanese, whom they considered inferior and barbaric. The long foreign incursion convinced Chosun to close the nation from all foreign contact. Korea remained a "Hermit Kingdom" until it was forced to open in the late nineteenth century.

\section{Korea in the Modern Period}

\section{(1) Toward Colonization}

China's tributary system ended with the arrival of Western powers in Asia and the rise of Japan in the nineteenth century. From the mid-nineteenth century until the beginning of Japanese occupation in 1910, Korea went through turbulent modernization and fell victim to rivalry among imperialist powers (Zhao 1997, 7). In the midst of fierce competition between China, Japan, Russia, and other imperialist powers over the Korean peninsula, the Chosun Kingdom experienced severe internal divisions that further weakened national power. Despite efforts by King Gojong to maintain national sovereignty and independence, Korea's fate was yet again largely determined by external powers.

Thanks to successful industrialization and modernization efforts, Japan challenged Chinese hegemony and emerged as a new major power in Asia by the late nineteenth century. With the rise of Japanese power and decline of Chinese hegemony, the traditional unipolar hierarchic international system in East Asia was replaced by an anarchic modern nation-state system (Kim 2001). For Japan, colonization of Korea was a necessary step for its expansion into Asia's heartland. The first step toward colonization of Korea took place in 1876. Adopting the same strategy used by America in 1854, Japan coerced Korea to open ports and sign a Chosun-Japan defense treaty, the first modern and unequal treaty for the Koreans that significantly compromised Korea's sovereignty.

After the forced opening in 1876, Chosun signed treaties with Western powers also. However, the Western powers that Chosun expected to help against growing 
Japanese aggression eventually supported Japan's occupation of Korea. For China, on the other hand, Korea was too important to lose. Besides the historical importance of the peninsula for national security, the Chinese sought to retain influence over Korea in order to check Japanese expansion in the region. Under pressure from the imperialist powers, the political elites of Chosun were divided into pro-China conservatives and pro-Japan reformers. Reformers, supported by King Gojong, were impressed by Japan's rapid modernization and sought to emulate it. However, the reformers were too weak to suppress conservatives trying to preserve the existing international system centered on Chinese hegemony, and the reformers' Kapsin Coup d'Etat of 1884 failed. The division of Chosun's political elites further weakened national power (Cumings 1997, 94-115).

Rivalry between China and Japan over the peninsula and East Asian hegemony erupted into the Sino-Japanese War in Korea in 1895. Chosun attempted to avert military conflict between the two powers diplomatically, but in vain. Despite the defense treaties with Chosun, all the major powers, including the United States, the UK, and Russia, declared a policy of non-intervention in the SinoJapanese War. Contrary to the expectation of many, Japan easily won the war. In April 1895, the Treaty of Simonoseki between Japan and China effectively ended Chinese dominance over Korea.

After the defeat of China, Japan sped up the process of colonizing Korea. Meanwhile, within Chosun, strong anti-Japanese sentiment grew rapidly, and many political elites of Chosun turned to Russia for help. Backed by the Chosun government, Russia began to intervene in Korea's domestic affairs. To achieve their goal of colonizing Korea, Japan had to oust the Russians from the peninsula. In 1904, the Russo-Japanese War broke out, and again Japan surprisingly won. In 1905, the Treaty of Portsmouth removed Russian power from the peninsula for good, and Japan's dominance over Korea was firmly approved by the United States and Britain, who considered Russia a bigger threat and wanted to check expansion of Russian power in Asia (Kim 1993, 9). In a secret agreement with his Japanese counterpart in 1905 at Portsmouth, U.S. President Theodore Roosevelt approved Japan's dominance over Korea in exchange for Japan's approval of U.S. dominance over the Philippines (Cumings 1997, 125, 141-143; Lee 1997, 136-137). By defeating China and Russia and getting support from Western powers, Japan was free to force the Chosun government to sign a treaty depriving Chosun of its diplomatic powers in 1905, thus constituting the death of the Korean state. Finally, in 1910, Japan annexed Korea. Against harsh international power politics, there was little Chosun could do to protect its independence from Japan.

(2) Japanese Colonial Era, Independence, and Division (1910-1950)

From 1910 to 1945, Korea was a colony of Japan. Throughout the occupation, 
Koreans struggled for independence and Japan relied on brute force to suppress independence movements. The early years of Korean resistance to Japanese occupation took the form of uibyong (righteous army) armed struggle by partisan irregulars, beginning in the late nineteenth century. Uibyong armed struggle declined due mainly to the overwhelming military power of Japan. Japan's heavy-handed military policy evoked mass resistance in Korea and finally led to the nationwide peaceful demonstrations of March 1919, later called Sam-Il Undong (March First Movement). The demonstration forced Japan to adopt a more moderate cultural policy toward Korea and initiated a new and dedicated independence movement.

From the 1920s, Korea's independence movement, inspired by different philosophies and ideologies, was divided into communists and nationalists. Many nationalist leaders left Korea after the 1919 independence movement and established the Korean Provisional Government in Shanghai. Meanwhile, Korean communist groups organized in Manchuria conducted partisan activities against the Japanese. The Soviet Union and Mao Zedong supported the communists and Chiang Kai-shek supported the nationalists, yet external support was often unreliable and hopelessly insufficient and was always subject to a rapidly changing international environment. Within Korea, various groups strove to enlighten the masses and preserve Korean identity under harsh colonial oppression. In short, Korea's independence movement was divided and, recognizing its shortcomings, attempted to form alliances with external powers. However, despite a strong and assiduous struggle for independence, Korea failed to achieve independence for herself. Korea's independence came only after Japan's defeat in the Pacific War. With the news of Japan's surrender, Korea was filled with high hopes for political independence. However, the voice of the Korean people was largely absent from the process of deciding Korea's future after the war. In November 1943, Roosevelt, Churchill, and Chiang met in Cairo and discussed the "Korea issue." Their Cairo Declaration stated, "We recognize the enslavement of the Koreans by the Japanese and we declare, in due course, Korea shall become free and independent" (Hwang 1992, 515-516; emphasis added). The following Potsdam Declaration confirmed that the Cairo declaration should be enforced. Not surprisingly, Koreans were invited to none of these historic meetings.

Instead of giving Koreans full independence, the Allies divided the country and sent U.S. and Soviet forces to displace the Japanese army from southern and northern zones of Korea, respectively. Few then anticipated this military measure would become a permanent division of Korea. The United States and the Soviets arrived and began to extend their powers in South and North Korea, respectively, as occupiers. As the Cold War deepened and the rivalry between the United States and the Soviet Union intensified, the Korean peninsula once again emerged as a site of international struggle: neither superpower wanted the other to have full influence over this strategically located peninsula.

From 1945 to 1948 , Korea was occupied by rival superpowers: North by 
the Soviet Union and South by the United States. In 1948, led by the United States, the UN decided to hold an election in Korea and establish an independent nation. However, the Northern part of Korea boycotted the UN-authorized election. Therefore, South Korea alone held the election and established the Republic of Korea; the establishment of a communist regime in North Korea followed a month later. Korea's geographic location made her vulnerable to the superpower proxy war that broke out in June 1950 after the invasion of South Korea by North Korea, which had received permission from Moscow. The United States responded quickly and pressured the UN Security Council to send UN forces to protect South Korea. For the United States, Korea had become strategically vital for its containment policy when China fell into the hands of the communists in 1949. South Korean-UN combined troops, led by General MacArthur, soon turned the tide of war and had conquered most of the peninsula when China suddenly joined the war supporting North Korea. China viewed an anti-communist regime in neighboring Korea as a security threat. ${ }^{4}$ An armistice was signed in 1953. The three year long Korean War devastated the peninsula, and solidified the national division between the two Koreas, which had been one nation for more than one millennium.

\section{(3) Korea under the Cold War System ${ }^{5}$}

The two Koreas have confronted each other now for more than half a century. The division of the Korean nation resulted from Cold War competition between the superpowers, and it remains the defining factor in the two Koreas' security predicament. Not surprisingly, during and after the Korean War, South Korea became the bulwark of the U.S. bloc, mainly because of its strategic location. Since the division, there has been fierce competition between the two Koreas in every sector, especially in security. Throughout the Cold War, South Korea and the United States maintained a solid bilateral security alliance relationship. They signed the Mutual Defense Treaty in 1953 after the truce ending the Korean War. The core of the agreement was for the United States to provide South Korea with a security umbrella and station U.S. forces in South Korea. South Korea accepted the loss of some sovereign authority by allowing the stationing of American troops on its territory. Thus, Seoul's foreign policy was heavily influenced by the U.S. Cold War policy of containment. Regimes in Seoul were supportive of U.S. policies and grateful to U.S. forces in Korea. Despite some friction, Korea's alliance with the superpower was a decisive factor in Seoul's foreign policy during the Cold War. Unfortunately for both South and North Koreans, the much-heralded end of the Cold War around 1990 did not mean much, since the peninsula remains divided today and the little cold war continues.

Oberdorfer (1997) succinctly summarizes the misfortune and dilemma of Korea's 
modern history:

Korea has been a country of the wrong size in the wrong place: large and well located enough to be of substantial value to those around it and thus worth fighting and scheming over, yet too small to merit priority attention by more powerful nations on all but a few occasions. Korea's fate was often to be an afterthought, subordinated to more immediate or compelling requirements of larger powers, rather than a subject of full consideration in its own right.

\section{POLAND}

\section{Poland before Partition (1795)}

With a recorded history dating back to 965 C. E., Poland became powerful and well established through territorial expansion and was recognized as a respectable power by the mid-fourteenth century. 6 Through a union with Lithuania in the late fourteenth century, Poland became multinational and diverse in culture and religion. Poland engaged in conflicts with the Teutonic Knights and the Muscovites. The Treaty of Lublin in 1569 paved the way to electing the king based on constitutional requirements. The Republic of Poland-Lithuania began with the first election in 1572 and lasted until 1795.7

Until the eighteenth century, the Republic maintained a powerful army and participated in major military campaigns in eastern and northern Europe, fighting with or against Russians, Swedes, Prussians, Turks, etc. However, economic difficulties and armed rebellions severely impeded internal cohesion and brought about inevitable decline. In addition, the Republic's failure to build a strong central administration proved costly (Lukowski 1991, 7). With the rise of neighboring Prussia, Russia, and Austria in the seventeenth century, the Republic, weakened by internal problems and war exhaustion, ceased to be a significant regional actor by the beginning of the eighteenth century. The Great Northern War (1700-1721) was the deathblow. Peter the Great of Russia, the victor, forced the Polish-Lithuanian Republic to become almost a Russian protectorate in 1717. As soon as Poland lost its status as a respectable competitor in Eastern Europe, its affairs were determined mainly by external powers. The election of the King of Poland constantly met with interference from outside agents who wanted their own candidates elected. By the mid-eighteenth century, Russia assumed the prerogative to freely intervene in Polish affairs in the name of security and gradually came to treat Poland as a client state (Luard 1996, 123, 164). 8

The Russian Czarina Catherine, who wanted to keep Poland weak and divided as a client buffer for her country, proposed a partition of Poland to her neighbors 
Prussia and Austria. In 1772, the first partition of Poland was agreed among Catherine, Frederick the Great, and Maria Theresa; they took about one-third of the territory and population of the Republic. Despite this humiliating event, internal reforms in Poland continued, and in 1791 the "Four Year Sejm" produced the most advanced and democratic Constitution at the time. Yet this remarkable achievement angered the Russian Czarina, and she pushed for a second and third partition of Poland in 1793 and 1795. Poland was wiped off the map of Europe in 1795, and its return as an independent state took more than a century. 9

\section{Poland in the Modern Period}

\section{(1) Poland Partitioned (1795-1918)}

During the Partition, the absolute priority of the Polish was to reclaim sovereignty and to preserve national identity. To this end, two schools emerged, Idealism and Realism (Bromke 1967; Davies 2001, 2005).10 Idealists were Romanticists who had nostalgic memories of the old Republic, like the heroic romanticist Kosciuszko in the late eighteenth century, and bitterly resented the injustice of the partitions. As insurrectionists, they were committed to achieving national independence at all costs. Realists, on the other hand, argued that since Poland's geopolitical position could not be altered, every national effort must be made based on recognition and acceptance of this hard reality. Also known as Positivists who strived for organic reform, Realists worked hard to improve general conditions for Poles through education, science, etc., and were more conciliatory toward the state authority of the partitioning powers. ${ }^{11}$

However, notwithstanding the internal efforts and sacrifices, the external environment proved decisive for the fate of the Polish nation. Hope and despair all came from outside. Napoleon's France, which considered Poland a natural ally to contain Prussia, provided hope for Polish independence by defeating the partitioning powers one after another. Yet the Duchy of Warsaw (1807-1815), created by Napoleon, did not survive his downfall. At the Vienna Conference, the Polish Question was discussed and debated. However, the physical occupation of Russia and stubbornness of the Czar were too much to overcome for delegates from Britain and France who sympathized with the Polish cause (Davies 2001, 142; Slantchev 2007, 587-89). The much-heralded Concert of Europe was only for major powers. Poland was treated as territorial compensation among the partitioning powers, and it served the European conservatives of both east and west as a way to preserve a workable equilibrium among themselves (Gulick 1982).

During the Crimean War in 1854, Polish hopes were revived that Britain and France might come to their rescue. However, because of possible intervention by Prussia and/or Austria on the Russian side, the two Western powers abandoned 
the idea of resurrecting Poland (Davies 2005, 256). With the unification of Germany and the decline of the Austrian Empire after 1871, Poland was situated precisely between two hostile and aggressive giants, Russia and Germany. Neither was interested in changing the status quo regarding Poland. German Chancellor Bismarck's position was firm that any kind of independent Poland constituted a direct threat to Germany's national interests and hence would never be allowed (Blanke 1981, 8-9; Mearsheimer 2001, 3). ${ }^{12}$ By the turn of the century, the Polish Question was largely forgotten in Europe. Even in Poland, divisions in activist camps and between classes and different nationalities, made a coherent effort extremely hard. Few in that time thought of a revival of an independent Polish nation. The Polish Question reappeared only with the outbreak of the First World War. ${ }^{13}$

At the beginning of the Great War, the two opposing camps in Poland developed different strategies. The Pilsudski-led camp participated directly in military campaigns on the Central Powers' side through the Polish Legions, whereas the Dmowski-led camp tried to link with the Allied Powers mainly through diplomatic means. All three partitioning powers offered significant concessions to the Poles in exchange for their assistance (Roeder 2007, 333). Western powers also promised to grant independence for Poland. At the end of the war, Poland finally gained independence in an unforeseen way. While Dmowski was in Paris, Pilsudski, imprisoned by the Germans in the middle of the war because they doubted his loyalty, was released and sent to Warsaw by German authorities in expectation of a new Poland that would be friendly to Germany. After more than a century's hiatus, Poland was reborn: all three partitioning powers had been defeated or transformed and were no longer able to hold onto Poland.

\section{(2) The Second Republic and the Second World War (1918-1945)}

Surprised but delighted, the Second Republic of Poland under the leadership of Pilsudski tried hard to make the nation fully independent and powerful again to avoid another national humiliation. In defiance of the Paris Peace Conference, the Poles gained territory and drew their borders themselves through a series of wars with neighbors (Davies 2001, 100). ${ }^{14}$ Since Poland had to secure the new borders of the Second Republic without the assistance of anyone else, including the West, "the Poles came to distrust the Great Powers while acquiring an exaggerated belief in their own military capabilities" (Lukowski and Zawadzki 2005, 232).

However, the new Poland was not welcomed by many, especially among her neighbors. Germany immediately resented the new border with Poland, which set the Polish Corridor between the homeland and East Prussia. In their irredentist claim, Weimar leaders were no less aggressive and resentful than Hitler. Moreover, the German complaints appealed to the Western democracies. The only friend 
that Poland could find, a remote and unreliable one, was France, a traditional ally who was working to build a series of alliance structures in Eastern Europe to encircle Germany (Kennedy 1987, 277; Schweller 1999, 122). The two formed a defensive alliance in 1921. However, in a prelude to a larger conspiracy less than two decades later, the two revisionist powers of Europe, Germany and the Soviet Union, signed the Rapallo Agreement of 1922 and instantly drew an ominous cloud over post-War European stability (Korbel 1963, 116-17).

In the Treaty of Locarno of 1925, in which Poland was not invited, participants agreed to accept the western borders, but the issues of the eastern borders were deliberately omitted by German demand and Western acquiescence. It was clear the West wanted to restore the traditional balance of power in Europe, and to this end the traditional major actors of Germany and Russia needed to be re-strengthened even if that meant sacrificing smaller states like Poland. Thus, in border issues the Western powers sided with Germany or Russia (Cienciela and Komarnicki 1984). Poland's internal conditions were not favorable either. Its society was still deeply divided and the economy was weakened. Bitterly disappointed by the corruption and incompetence of the Constitutional leadership established in 1921, Pilsudski waged a successful military coup in 1926 and led Poland until his death in 1935.

In the foreign policy arena, Pilsudski showed little trust of outside powers, owing to past experience, and strove to strengthen Poland's national power. He promoted the Doctrine of Two Enemies but tried not to antagonize either one. Yet when Hitler gained power in Germany, Pilsudski seriously contemplated a preventive war against the Nazis. The plan was abandoned due to Western hesitation (Stachura 1998, 144). Instead, he signed non-aggression treaties with Poland's two powerful neighbors: the Soviet Union in 1932 and Germany in 1934. After Pilsudski's death, Colonel Beck, the Minister of Foreign Affairs, followed Pilsudski's principles to "uphold proper relations with both neighbors, but to ally with neither" (Davies 2001, 110; Debicki 1962, 89). During the Rhineland Crisis in 1936, Beck was willing to aid France should events require. Yet the West abstained, causing Beck to doubt Western capability and determination. Warsaw quietly accepted Anschluss, because it did not want relations with Hitler to sour, knowing Western powers would sit idle (Polonski 1972, 473-475).

After witnessing Britain and France suing for peace with the Nazis at the expense of neighboring Czechoslovakia in Munich in 1938, the Polish leadership realized Poland was next on the list of Hitler's insatiable aggression. Yet they had few choices. They still had to rely on unreliable Western powers who promised to protect Poland from the German war machine. Following Pilsudski's formula, Warsaw also refused to give in to demands by the Soviets and Germans to side with one or the other in the upcoming conflict between the two, thus "hiding in independent neutrality" (Schroeder 1994, 123). Yet like Pilsudski, 
Beck tried to preserve good relations with Hitler, since he regarded the Russians as the more inveterate enemy (Polonski 1972, 470-83).15 Recognizing the Western powers' inability to keep their word to Poland, Hitler and Stalin signed the Non-Aggression Pact in late August, 1939. Poland was doomed. Despite warnings from London and Paris, Germany invaded Poland on September 1, 1939, igniting the Second World War. The Red Army followed suit two weeks later. Help from the West never came. The League of Nations provided collective security in name only. Poland was occupied and partitioned only twenty years after independence. The Poles fought at home and abroad under the leadership of the Polish government-in-exile in London.

When the discussions over post-War settlements started in November 1943, in Teheran, the "Big Three" Western powers had to comply with Stalin's adamant demands, since his Red Army was carrying the lion's share of the fighting against Hitler's Wehrmacht. Stalin wanted to divide post-War Europe into zones of influence, and according to his scheme, Eastern Europe, including Poland, would be under Soviet control as a buffer. In the subsequent Conferences of Yalta and Potsdam in 1945, the Soviet project for Eastern Europe was confirmed. The Polish eastern border with the Soviets was the controversial Curzon Line, which meant Poland ceded almost half its prewar territory. Territorial compensation was made in the north and west at the expense of the defeated Germans. 16 All this was devised and promoted by Moscow; the Poles were never even informed of these crucial decisions for their nation. ${ }^{17}$ Western powers paid attention only to their own national interests. On the Polish Question, "Anglo-Saxon viewpoints in general, and British viewpoints in particular, were dictated not only by the traditional concern for the balance of power, but even more by the logic of traditional alliances. In two World Wars, Great Britain was allied with Russia and counted on Russian manpower and on Russian sacrifices for the defeat of the German armies" (Davies 2005, 368). ${ }^{18}$ Despite all the sacrifices, suffering, and the loss of more than six million lives, true independence and sovereignty eluded the Poles: Poland became a satellite state of the Soviet Union. A century and a half of struggle for independence had produced a fundamentally limited and flawed independence for Poland, except for a brief period of two decades in the early twentieth century. Davies (2005, 11-12) summarizes the grave misfortune of Poland during this period:

At each of the main peace conferences-at Vienna in 1814-1815, at Paris in 1919-1920, and at Yalta and Potsdam in 1945-Poland's future was discussed and debated at great length. In between the wars and conferences, formula after ill-fated formula was invented in attempts to reconcile the demands of the Polish with the interests of the ruling powers. For 150 years, the Polish Question was a conundrum that could not be solved, a circle that could not be squared. $\cdots$ At each of these critical moments, matters were not decided at the conference table, but by the situation on the ground and by the men 
who held the reins of practical power.

\section{(3) Communist Poland and the Cold War (1948-1989)}

Stalin was determined to eradicate the influences and legitimacy of the Polish government-in-exile in London. In 1943 he severed the fragile relationship between them that had existed since the Nazi invasion of the Soviet Union in 1941. The ill-fated Warsaw Uprising in 1944 effectively decimated pro-London Poles through the deliberate neglect of the Red Army. The Soviet agreement with Western powers to include the London Poles and to have a free election was never realized. By 1948, a new Poland, the Polish People's Republic, was under firm Soviet control through the Polish United Workers' Party (PZPR). Aside from tension caused by Gomulka's maverick policy in 1956, Warsaw in general acted in sincere conformity to the general foreign policy of the Soviet Bloc.

A serious foreign policy concern for Warsaw was resentment in both West and East Germany regarding the border at Oder-Neisse. In this matter, the East German government was no less resentful than its Bonn counterpart: socialist solidarity and internationalism faded before parochial national interests (Anderson 2001). The position of the United States on this matter was again in favor of Germany (West) because of the strategic importance of West Germany during the Cold War. The agreement signed between Warsaw and Bonn in 1970 reaffirmed the Polish western border. The Helsinki Agreement in 1975 confirmed the existing borders of Eastern Europe. Yet the United States hesitated to ratify the agreement. True resolution of the Oder-Neisse border dispute came only after around the time of German unification in 1990 (Allen 2003, 287-289).

Poland's external security from 1955 depended on the Warsaw Pact: Poland had a client relationship with Moscow. Serious and unprecedented changes and challenges occurred in Poland in the 1980s via the Solidarity movement, and a great and unexpected source of change came in the mid-1980s from the East. The new Soviet leader Gorbachev's path-breaking policies of Perestroika and Glasnost and the revocation of the Brezhnev Doctrine paved the way to fundamentally reform the whole Soviet bloc. The Roundtable Talks peacefully transferred power from Poland's Communist leaders to democratic opposition leaders, led by Lech Walesa. A free election soon followed. In 1989, Poles finally achieved true independence and self-determination for themselves.

\section{COMPARATIVE ANALYSIS OF KOREA AND POLAND}

How, then, did Korea and Poland respond to external threats? Did they balance or bandwagon or something else? Do Korea and Poland exhibit similar foreign policies? Our examination of the history of the two countries demonstrates several 
meaningful shared patterns of foreign policy behavior. First of all, due to their geography, both Korea and Poland became objects of power struggles between neighboring major powers, and outsiders often determined the fate of each nation. External conditions made balancing efforts against external threat nearly impossible. Also, both experienced sharp domestic divisions when threatened by the external powers, which further weakened the internal cohesion and national power of the two countries. Lastly, in both Korea and Poland, ideational factors sometimes played an important role in foreign policy choices, demonstrating the limitation of the neorealist approach. We will explain each of these points in detail.

Throughout its history, external influence has decided Korea's fate. Under the Chinese-centered tributary system, there was no practical need for Korea to balance or bandwagon. Yet the Chinese hegemonic system subjected Korea to internal strife during power transitions in China, and occasionally Seoul sought China's help to ward off aggression, as in the case of the Japanese invasion in the late sixteenth century. After the decline of Chinese unipolarity in the late nineteenth century, Korea turned to non-Asian powers to balance Japanese aggression. These countries were either defeated by or colluded with Japan. After 35 years of occupation, notwithstanding tremendous efforts by Koreans to gain independence, their fate was decided by the Allies of World War II in a series of conferences. The brutal result of the great power negotiations was the division of the Korean Peninsula by the two superpowers in 1945.19 The peninsula soon became a Cold War battleground and remained one of the most dangerous places on earth throughout the Cold War. Under these circumstances, it was inevitable that Seoul accepted security as a partner of the United States. Despite a few setbacks, this asymmetric bilateral alliance structure remains the linchpin of South Korean security. Thus the United States came to serve as the "reliable" great power ally Korea lacked in its earlier history.

Poland's geopolitical location created circumstances and results very similar to those of Korea. Despite remarkable efforts, the Polish nation fell victim to overwhelming external forces time after time. After losing major power status in the early eighteenth century, Poland became an expendable prize to maintain balance within the great powers of the "Concert of Europe." Her eastern and southern neighbors in similar misfortunes were too small even collectively and too divided to form any meaningful counter-structure against the dominant powers. Western powers sympathetic to the Polish cause, like France and Britain, subjugated that sympathy to their national interests and the long-term power equilibrium of Europe. Thus Poland's two powerful and most aggressive neighbors, Germany and Russia, had a free hand in Poland. On the eve of the partitions in the 1790s, Poland attempted to balance but failed and ceased to exist. Before the Second World War, Poland did not join a partnership with either potential 
aggressor. It tried to stay neutral or "hide" against insurmountable odds, with token hope held out by the Western allies. But Poland was occupied and partitione d. 20 Thus, for a buffer state like Poland, balancing efforts are futile. This logic certainly applies to Korea as well. At no point in the past century or more could Korea successfully balance, hide, or hedge. Their territory was the object of an inter-power rivalry rather than simply being coveted by a larger power for its own sake. Thus, the stakes (and the concessions demanded) were so high for the major powers as to render the buffer state completely unable to maneuver.

As Fazal (2007, 109) argues, the powers surrounding Poland were more concerned about potential strategic gains its rivals might make by conquering the buffer (Poland) than the value of Polish territory itself. The same logic applies to rivals for Korea. Park (2006) argues that Beijing intervened militarily when a rival power invaded Korea (1592, 1894, and 1950) or when the Korean leadership allied with a political rival for the dominance of China (1627). Thus, the geographic locations of Korea and Poland provided strong incentives for powerful neighbors to acquire their territory, since they could not afford to lose it to their rivals. Neither state possessed sufficient capability and influence for effective balancing. Internal division when threatened by an external power is another commonality between Korea and Poland. When there was a power transfer in the region, the ruling class of Korea was often divided, further weakening its national power. In the traditional era, the Korean elite became divided over regime changes in China, as shown in the transition from the Ming to the Qing. At the turn of the twentieth century, the Chosun government was divided into pro-Japan, pro-China, and pro-Russia factions. During the Colonial period, the Korean independence force was divided mainly into Nationalists and Communists. Despite significant achievements and sacrifice, such division limited Korea's power.

Poland's internal division was no less costly. Before the partitions, a proud heritage of democracy and diversity was a stumbling block to the development of effective central administration and cohesive military forces. During the partition period, rivalry between Realists and Idealists significantly hampered development of a unified struggle against the occupying powers. Each camp sought sympathetic forces outside Poland who proved to be completely unreliable. During World War II, the division and the unrealistic expectations of different groups made them vulnerable to unexpected changes in external conditions and eventually contributed to submission to Soviet power.

Ideational and normative factors often provided significant input in the decision-making processes of both Korea and Poland. In the case of Korea, ideational factors such as Confucian principles played an important role in deciding foreign policy. When there was a conflict for control of China, Korea often sided with a "morally just" contestant, following long-held Confucian convictions and disregarding the reality of material capability between the competing powers. Another 
important ideational factor is Koreans' deep-rooted view of the Japanese. Koreans always considered themselves more civilized and superior to the barbaric island people, even after (or because of) the Japanese invasion of 1592. When Japan rapidly modernized and adopted the Western system in the late nineteenth century, many Koreans saw that as further evidence of Japanese deviance from the great Sinic world (Eckert 2000, 127; Cumings 1997, 99-100). Although reform-minded people in Korea supported the Japanese modernization model, many of the Korean elite were still preoccupied with the great Chinese culture and the Chinese-centered tributary system. These ideational factors make it difficult for a realist to explain Korea's foreign policy: in many cases, its foreign policy does not follow the pattern of small powers predicted by realists.

The Polish case also shows the importance of non-material considerations. The Poles viewed themselves as important and different from the rest of Eastern Europe. They upheld a democratic and republican tradition for centuries when absolutism and despotism prevailed elsewhere in Europe, including Western Europe. ${ }^{21}$ They believed their position in the heart of Europe made them indispensable for the preservation of the European balance of power (Prizel 1998, 26). However, this belief turned out to be a fatal mirage. The Western powers did not consider Poland one of their own: Poland was in a remote and still barbaric area of the periphery of Europe, and its culture and civilization were hardly known to them (Cienciala and Komarnicki 1984, 4-6). Poland was too far from the West and it offered little direct material benefit for London, Paris, or later, Washington. The United States and NATO saw Poland only within the context of its relationship with Moscow (Allen 2003, 6). France and Britain viewed the Polish Question only as part of the German or Russian problem (Cienciala and Komarnicki 1984, 9).22 Certainly, the Polish feeling of moral superiority and sense of belonging to the West did not and could not save them from the real weapons and bullets of Germany and Russia. Moreover, the painfully wrong sense of grandeur and self-perception as a great power current among the Polish elites in the 1920s and 1930s "contributed to a scrappy diplomacy that resulted in Poland's perpetual poor relations with all of its neighbors" (Prizel 1998, 69). The point here is that, in order to accurately understand Polish foreign policy in historical perspective, one must consider ideational factors. ${ }^{23}$

\section{CONCLUSION}

This historical comparative analysis of Korea and Poland seems to vindicate an old axiom of realism regarding the fate of smaller powers in international politics: "The weak suffer what they must." Korea since the late nineteenth century and Poland since the late eighteenth century experienced extreme hardships and national humiliations one after another. We have emphasized that, for these 
two countries, geographic location and geopolitics are the decisive cause of their sufferings. ${ }^{24}$ We have also shown that Korea and Poland neither balanced successfully nor bandwagoned when confronted with external threats. As mentioned before, balancing was not an effective strategy because of limited material capabilities and the "underbalancing" caused by internal division and fragmentation of leadership. Moreover, it was extremely hard to find a reliable major power ally. They did not, and could not, bandwagon either, because they were the direct targets of aggression, due to their strategic locations. When their territories were targeted, their fates were sealed from the beginning. ${ }^{25}$ The geographic locations of the two countries, sandwiched between powerful neighbors, fundamentally limited their policy options. Major Western powers at a distance from the two countries usually acquiesced and sometimes even supported the unjust invasions of Korea and Poland by their neighbors. In addition, we have highlighted the fact that, when external forces threatened Korea and Poland, ideational factors played more important roles in their responses than neorealists would like to admit. Both nations often made policies based on cultural, normative, or customary beliefs or principles rather than the calculation of material capability and threat perception.

The writings of prominent scholars on each nation, Korea and Poland, could be applied interchangeably to characterize the other nation. For example, Prizel (1995a, 98) advises that "First, Poland had to break with its tradition of cataloging the historic wrongs inflicted upon it by its neighbors, which invariably dragged Poland into a diplomacy of bombastic symbolism. And second, despite the limelight that Poland might currently enjoy, Poles could not forget that theirs is a mid-sized European state with limited resources; under no circumstances could Poland act beyond its actual capabilities." The analysis of Poland makes sense in describing Korea: simply replace Poland with Korea and Europe with Asia. We also believe that each must learn from its history to become truly independent as well as to contribute to peace and prosperity in their respective regions. 26

Scalapino $(1998,15,32)$ argues on the situation of Korea (and it applies equally to Poland) that, "United or divided, Korea is a small country surrounded by giants. $\cdots$ Under these circumstances, it has had three basic options in selecting the foundation for its foreign policy: isolation, alignment with one or more major powers, or balance-of-power politics." Isolation is out of the question in the twenty-first century. Both South Korea and Poland are too weak to be an individual player in balance of power politics, and so they must align with a big power. The two were formerly unable to find a reliable major power ally. South Korea and Poland have become allies of the United States, the former through the bilateral alliance since 1954 and the latter by joining NATO after the end of the Cold War. Although the alliance structure with the United States has become essential for both nations, both now want more say in the alliance structure. Seoul and Warsaw's post-Cold War security policies reflect 
their geographic locations and their relative strengths as well as newfound confidence derived from recent economic and political development and traditional national pride. Their pursuit of diversified security relations while adhering to the U.S. alliance structure reflects the behavior of medium states whose geopolitical placement forces them to behave in certain respects like small states. Both Seoul and Warsaw can be expected to strive for preservation of the status quo (a prominent feature of which is the security structure with the United States), pursue defensive strategies and military modernization, and engage in diversified security arrangements or a multilateral framework without disrupting their alliance with the major power. This tendency is especially important nowadays, since Korea and Poland have strong reason to be concerned about the resurgence of China and Russia in their respective regions.

Each of these nations has been "a shrimp between two whales" but now seems to be trying to become "a small but piquant pepper." The piquant pepper, another Korean expression, is one whose effect belies its size. Historically, both nations have been mistreated by major powers, but the two nations should not be fatalistic or even pessimistic. Seoul and Warsaw need to take advantage of their strategic locations and strive to focus on niche areas to make them indispensable to their respective neighbors. ${ }^{27}$ The twenty-first century provides them something they could not enjoy before: the richness and effectiveness of global and regional institutions. ${ }^{28}$ The two nations should strive to preserve and/or develop existing institutional structures to maintain their security. They also need to work hard to contribute to world peace and stability based on their relative affluence and material capability as medium powers. Whether history will repeat itself or not depends this time on Korea and Poland themselves.

\section{REFERENCES}

Allen, D. 2003. The Oder-Neisse Line: The United States, Poland, and Germany in the Cold War. Westport, CT: Praeger.

Anderson, S. 2001. A Cold War in the Soviet Bloc: Poland-East Germany Relations, 1945-1962. Boulder, CO: Westview Press.

Art, R. 2004. Europe Hedges Its Security Bets. In Balance of Power: Theory and Practice in the $21^{\text {st }}$ Century, eds. T. V. Paul, James Wirtz, and Michael Fortmann. Palo Alto, CA: Stanford University Press.

Bang, H. S. 2005. Han-Jung Oe-gyo Guan-gye ua Jo-gong Chaek-bong [Korea-China relations and tributary system]. Seoul: Korea Research Institute.

Blanke, R. 1981. Prussian Poland in the German Empire (1871-1900). Boulder, CO: East European Monographs distributed by Columbia University Press. Borzecki, J. 2008. The Soviet-Polish Peace of 1921 and the Creation of Interwar Europe. New Haven, CT: Yale University Press. 
Bromke, A. 1967. Poland's Politics: Idealism vs. Realism. Cambridge, MA: Harvard University Press.

Buzan, B., and R. Little. 2000. International Systems in World History: Remaking the Study of International Relations. New York: Oxford University Press.

Cienciala, A., and T. Komarnicki. 1984. From Versailles to Locarno: Keys to Polish Foreign Policy, 1919-1925. Lawrence, KS: University of Kansas Press.

Cumings, B. 1997. Korea's Place in the Sun: A Modern History. New York: W. W. Norton.

Davies, N. 2001. Heart of Europe: The Past in Poland's Present. New York: Oxford University Press.

Davies, N. 2005. God's Playground: A History of Poland, Vol.2: 1795 to the Present. New York: Columbia University Press.

Debicki, R. 1962. Foreign Policy of Poland 1919-1939: From the Rebirth of the Polish Republic to World War II. New York: Frederick Praeger.

Donnelly, J. 2000. Realism and International Relations. New York: Cambridge University Press.

Dunn, D. 2003. Poland: America's New Model Ally. In Poland-A New Power in Transatlantic Security, eds. Marian Zaborowski and David Dunn. London: Frank Cass.

Eckert, C. 2000. Korea's Transition to Modernity: A Will to Greatness. In Historical Perspectives on Contemporary East Asia, eds. Merle Goldman and Andrew Gordon. Cambridge, MA: Harvard University Press.

Elman, M. 1995. The Foreign Policies of Small States: Challenging Neorealism in its Own Backyard. British Journal of Political Science 25 (2): 171-217.

Fazal, T. 2007. State Death: The Politics and Geography of Conquest, Occupation, and Annexation. Princeton: Princeton University Press.

Frost, R. 2005. Ordering the Kaleidoscope: the Construction of Identities in the Lands of the Polish-Lithuanian Commonwealth since 1569. In Power and the Nation in European History, eds. Len Scales and Oliver Zimmer. New York: Cambridge University Press.

Goh, E. 2007/8. Great Powers and Hierarchical Order in Southeast Asia: Analyzing Regional Security Strategies. International Security 32(3): 113-57.

Gulick, E. 1982. Europe's Classical Balance of Power: A Case of the Theory and Practice of One of the Great Concepts of European Statecraft. Westport, CT: Greenwood Press.

Han, M. G. 2000. Myungcheong Gyochaegi Dongbooka Jilseoua Chosun Jibaecheong ui Dae-eung [International system of northeast Asian during MingQing transition period and response of Chosun leadership]. History and Practice 37: $124-48$.

Hawley, S. 2005. The Imjin War: Japan's Sixteenth-Century Invasion of Korea and Attempt to Conquer China. Seoul, Korea: Samhwa.

Hwang, Y. S. 1992. Geundae Dongyang Oegyosa [Diplomatic history of modern 
Asia]. Seoul: Myungji Press.

Kang, D. 2007. China Rising: Peace, Power, and Order in East Asia. New York: Columbia University Press.

Katzenstein, P., ed. 1996. The Culture of National Security: Norms and Identity in World Politics. New York: Columbia University Press.

Kaufman, S., R. Little, and W. Wohlforth, eds. 2007. The Balance of Power in World History. New York: Palgrave Macmillan.

Kennedy, P. 1989. The Rise and Fall of the Great Powers. New York: Vintage Books.

Kim, G. D. 1993. Foreign Intervention in Korea. Brookfield, VT: Dartmouth.

Kim, S. J. 2007. Hangook Joongsae Hanjungguangyesa [Korea-China relations in the medieval era]. Seoul: Hye An Press.

Kim, Y. G. 2001. Segyeguan Choongdol gua Hanmal Oegyosa [Clash of the worldview and diplomatic relations of the late Chosun period, 1866-1882]. Seoul: Moonhak gua Jiseong Press.

Korbel, J. 1963. Poland between East and West: Soviet and German Diplomacy toward Poland, 1919-1933. Princeton: Princeton University Press.

Labs, E. 1992. Do Weak States Bandwagon? Security Studies 1(3): 383-416. Lee, K. 1997. Korea and East Asia: The Story of a Phoenix. Westport, CT: Praeger. Lee, K. B. 1984. A New History of Korea. Translated by Edward Wagner with Edward Shultz. Cambridge, MA: Harvard University Press.

Little, R. 2007. The Balance of Power in International Relations: Metaphors, Myths and Models. New York: Cambridge University Press.

Luard, E. 1992. The Balance of Power: The System of International Relations, 1648-1815. New York: St. Martin's Press.

Lukowski, J. 1991. Liberty's Folly: The Polish-Lithuanian Commonwealth in the Eighteenth Century, 1697-1795. London: Routledge.

Lukowski, J., and H. Zawadzki. 2006. A Concise History of Poland. $2^{\text {nd }}$ ed. Cambridge: Cambridge University Press.

Mearsheimer, J. 2001. Tragedy of Great Power Politics. New York: W.W. Norton.

Morgenthau, H. 1984. Politics Among Nations: The Struggle for Power and Peace. $6^{\text {th }}$ ed. New York: Alfred Knopf.

Oberdorfer, D. 1997. The Two Koreas: A Contemporary History. New York: Basic Books.

Osica, O. 2003. In Search of a New Role: Poland in Euro-Atlantic Relations. In Poland-A New Power in Transatlantic Security, eds. Marian Zaborowski and David Dunn. London: Frank Cass.

Park, H. S. 2006. Shinhyunshiljueui ironeul tonghan junggukeui hanbando gunsagaeip yongu: 1592, 1627, 1894, and 1950 [A Neo-realist Study of China's Military Intervention in the Korean Peninsula: 1592, 1627, 1894, and 1950]. Korean Political Science Review 40(1): 163-82.

Paul, T. V., J. Wirtz, and M. Fortmann, eds. 2004. Balance of Power: Theory 
and Practice in the $21^{\text {st }}$ Century. Palo Alto, CA: Stanford University Press. Polonsky, A. 1972. Politics of Independent Poland 1921-1939: The Crisis of Constitutional Government. Oxford: Oxford University Press.

Prazmowska, A. 2004. A History of Poland. New York: Palgrave Macmillan. Prazmowska, A. 1995. Britain and Poland, 1939-1943: The Betrayed Ally. Cambridge: Cambridge University Press.

Prazmowska, A. 1987. Britain, Poland and the Eastern Front, 1939. Cambridge: Cambridge University Press.

Prizel, I. 1998. National Identity and Foreign Policy: Nationalism and Leadership in Poland, Russia, and Ukraine. Cambridge: Cambridge University Press.

Prizel, I., and A. Michta, eds. 1995. Polish Foreign Policy Reconsidered: Challenges of Independence. New York: St. Martin's Press.

Prizel, I. 1995a. Warsaw's Ostpolitik: A New Encounter with Positivism. In Polish Foreign Policy Reconsidered: Challenges of Independence, eds. Ilya Prizel and Andrew Michta. New York: St. Martin's Press.

Prizel, I. 1995b. Conclusion: Idealism or Realism: A Historical Dilemma or a False Dichotomy. In Polish Foreign Policy Reconsidered: Challenges of Independence, eds. Ilya Prizel and Andrew Michta. New York: St. Martin's Press.

Scalapino, R. 1998. Challenges Ahead. In The US and the Two Koreas: A New Angle, ed. Tong Whan Park. Boulder, CO: Lynne Rienner Publishers.

Schroeder, P. 1994. Historical Reality vs. Neo-realist Theory. International Security 19(1): $108-48$.

Schweller, R. 1999. Deadly Imbalances: Tripolarity and Hitler's Strategy of World Conquest. New York: Columbia University Press.

Schweller, R. 2006. Unanswered Threats: Political Constraints on the Balance of Power. Princeton: Princeton University Press.

Sheehan, M. 1996. The Balance of Power: History and Theory. London: Routledge. Slantchev, B. 2005. Territory and Commitment: The Concert of Europe as Self-Enforcing Equilibrium. Security Studies 14(4): 565-606.

Stachura, P. 1998. Poland between the Wars, 1918-1939. New York: St. Martin's. Vasquez, J., and C. Elman, eds. 2002. Realism and the Balancing of Power: A New Debate. Prentice Hall.

Walt, S. 1987. The Origins of Alliances. Ithaca, NY: Cornell University Press. Wendt, A. 1999. Social Theory of International Politics. Cambridge University Press.

Zaborowski, M., and D. Dunn, eds. 2003. Poland-A New Power in Transatlantic Security. London: Frank Cass.

Zhao, S. 1997. Power Competition in East Asia: From the Old Chinese Order to Post-Cold War Regional Multipolarity. New York: St. Martin's Press. 


\section{ENDNOTES}

1 Walt defines 'bandwagoning' as a state aligning with the source of danger.

2 The system was not a strict pyramid-like hierarchy. As Donnelly $(2000,86)$ argues, 'hierarchical subordination often was more cultural and metaphysical than political.' Kang agrees.

${ }^{3}$ Constructivism (Katzenstein 1996; Wendt 1999) has challenged (neo) realism's exclusive focus on material power and state interests in the international system, arguing that ideational and cultural factors intertwined in a society or system must be taken into account to truly understand the nature of international politics. Combining neorealist and constructivist perspectives, Evelyn Goh argues that the behavior of weaker states under threat would depend on 'high political and material costs of balancing strategies, threat assessments across issue areas, and cultural or ideational influences,' (Goh 2007/8, 127).

4 Analyzing the reasons of Chinese military intervention in Korea in 1592, 1627, 1894, and 1950, Hongseo Park (2006) argues that China, regardless of regime type, has sent troops to the Korean peninsula whenever they perceived their strategic interests were threatened.

5 For the sake of analytical comparison, we examine only South Korea from here on. As shown in South Korea's mirror image reactions to the North, Pyongyang's Cold War behavior also has been geography-motivated and security-driven. Yet not until the national division ends and the two Koreas are unified will the Korean state be truly resurrected. See Fazal (2007, 30, 32).

${ }^{6}$ For a historical background of Poland, see Davies 2001; Lukowski and Zawadzki 2006; and Prazmowska 2004.

A republican system in the age of absolute monarchs was possible because of the influence of a powerful and independent-minded Szlachta (nobility). The elected King and a common Sejm (Diet) ruled the country jointly.

${ }^{8}$ Breaks for the Polish reformers came only when Russia was at war with Turkey. However, when Russo-Turkish relationships became calm, Poland was in trouble at the hands of the Russians (Davies 2001, 305).

9 As Fazal $(2007,97)$ points out, late eighteenth century Poland is a classic example of buffer state death. attributable to the nation's geography.

10 Realism and Idealism in a modern Polish historical context should be distinguished from realism and idealism in IR. We capitalize Realism and Idealism to specifically indicate the two rival camps of the social and intellectual philosophy, culture, and movement in Poland.

11 Dominance in Poland by each of these two camps became almost cyclical (Bromke 1967, 7-51; Davies 2001, 145-85; Davies 2005, 23-35). When conciliatory gestures proved disappointing, the Romantic tradition revived in the November Rising of 1830 . Disillusioned by the dramatic failure of the January Rising in 1863, the Positivists took over the mainstream of Polish nationalism and led the Age of Organic Work until 1905. Arguably, thanks to the success of the organic work, newfound confidence allowed youngsters to dedicate themselves to fight for national independence, which was accomplished in 1918.

12 Positions toward the partitioning neighbors by the rival camps in Poland were also sharply different. The Nationalists, following the Realist tradition and championed by Roman Dmowski, saw the German Empire as the archenemy and promoted a rapprochement with Russia. In contrast, the Independence camp, virtually Romantic Idealists led by Josef Pilsudski, regarded Russia as the historic enemy and promoted an armed struggle against her, with possible help from Germany, to ultimately achieve full independence (Davies 2001, 113-29; 2005, 38-42).

13 As Davies $(2001,96)$ succinctly summarizes, "as long as the empires of Eastern Europe had been at peace, they had a common interest in suppressing the Polish issue; as soon as they were at war, they were compelled to compete with each other for Polish sympathies."

${ }^{14}$ Among these conflicts, the most remarkable was the Russo-Polish War in 1920-1921, which started when the Polish Army moved deep into Ukrainian territory. After changes of fortunes, the two sides, seeing no sign of decisive victory, signed the Treaty of Riga in 1921 and settled the eastern border (Borzecki 2008).

${ }^{15}$ He even cooperated with Germany during the Munich Crisis and afterward, although the amicable mood between Berlin and Warsaw soon ended (Prazmowska 1987, 15-17).

16 East Prussia went to Poland, and the Polish Western frontier expanded as far as the Oder-Neisse Rivers. Germans living in these territories were expelled (Allen 2003, 13-32).

${ }^{17}$ Many policymakers in Warsaw worried that extending Polish territory to the west at the expense of Germany would revive German revisionism and make Poland more dependent on the Soviet Union (Davies 2005, 373).

${ }^{18}$ See also Prazmowska's Britain and Poland, 1939-1943: The Betrayed Ally (Cambridge: Cambridge University Press, 1995) for a detailed analysis of divergent and often contradicting views and interests between the British government and the Polish government-in-exile in London. She argues the London 
Poles were abandoned not only by the Soviets but also by their supposed ally Britain because of British national interests, unrealistic and false Polish expectations, and political realities, of which the most important was the unexpected power and dominance of the Red Army.

19 Here, it is important to note that external powers had proposed division of the Korean Peninsula before. Since the war with Japan in the late sixteenth century, and especially during the late nineteenth and early twentieth centuries, it was a recurring theme for interested outside parties heedless of Korean sovereignty (Kim 1993, 1-8).

20 "Poland's attempt to balance against power could not be realized precisely because the powers it could turn to for help were interested in taking over Poland themselves" (Fazal 2007, 115).

${ }^{21}$ The Poles considered themselves an "integral part of Western civilization-Bulwark of Christendom" (Cienciala and Komarnicki 1984, 5).

22 Thus at the Paris Peace Conference, although Dmowski believed Poland was an equal and master of its destiny, delegates from other nations considered Poland a "client state, whose demands must be trimmed to accommodate the interests of its superiors" (Davies 2000, 367).

${ }^{23}$ Therefore, it is not surprising that most scholars of current Polish foreign policy strongly recommend coming down to reality: they advise starting with acceptance of the hard facts of the geography and relative capability of Poland (Prizel and Michta 1995; Prizel 1998; Zaborowski and Dunn 2003).

24 After all, as Fazal (2007, 37) argues, what matters is "location, location, and timing."

25 As Davies (2005, 316) says regarding the outbreak of WWII and the defeat and (re)partition of Poland, "it is obvious that Polish foreign policy under Colonel Beck did not save the Republic. But it is doubtful whether anything that the Polish government might have done could have made much difference." The same terms could describe what happened to Korea in the early twentieth century.

26 After all, Poland can "neither forget its history nor escape its geography" (Prizel 1995b, 166). Neither can Korea.

27 As Prizel and Michta (1995, xi) argue, peace, security, and prosperity for Poland will depend on the "ability to turn their geopolitical liability into an asset."

${ }^{28}$ Here is a lesson Korea needs to learn from Poland, since Polish security has greatly benefited from such institutions as NATO and the EU, effectively eliminating the traditional threat from Germany. Therefore, Seoul needs to work hard to transform the Six-Party Talks into a permanent multilateral security framework in Northeast Asia. 